УДК $1: 37.013 .73 ; 111.32 ; 130.123 .4$

Е. М. Герасимова, д. фрілос. н., профресор,

С. А. Крилова, д. фрілос. н., профресор

\title{
СОЦІАЛЬНИЙ ВИМІР ГЕНДЕРНИХ СТРАТЕГІЙ ОСВІТНЬОГО ПРОСТОРУ
}

Актуальність теми дослідження. Для сучасного українського суспільства особливої актуальності набуває проблематика глибинного осмислення концепту гендерної рівності. Такий інтерес зумовлено присутністю у сучасному освітньому процесі чоловіків $і$ жінок як у сфрері спілкування викладачів, так і на рівні взаємодії студентів або учнів.

Постановка проблеми. Сьогодні ми констатуємо появу нової якості стосунків між чоловіком та жінкою, які породжують неординарні ситуації у процесі постійної як професійної взаємодії, так і в побуті.

Аналіз останніх досліджень і публікацій. Започатковується розгляд теоретикометодологічних засад сучасного освітнього простору, у тому числі дослідження гендерних ресурсних можливостей в роботах таких українських фрілософрів як Л. Гармаш, Н. Доній, О. Зайченко, В. Калуга, О. Рубан, Т. Тройцька, Ф. Фомін тощо.

Виділення недосліджених частин загальної проблеми. Використовуючи патріархальний, фреміністичний та андрогін-аналітичні підходи авторами було запропоновано проаналізувати взаємодію та конструктивні можливості застосування таких гендерних стратегій у сучасному освітньому просторі, як маскулінно-субординативна, фомінно-координативна та андрогінно-цілісна або гуманістична.

Постановка завдання. Складність завдання, що пов'язана з підвищенням актуальності інтелектуального потенціалу гендерних стратегій для освітньої сфери діяльності, вимагає їх практичної адаптації до системи стратегічного управління національним освітнім простором.

Виклад основного матеріалу. Автори публікації вважають, що освітня проблематика завжди була невід'ємною складовою багатьох фрілософрських систем, тому що освіта у фрормі знання завжди володіла здатністю проникати у всі сфрери суспільного життя та мала всеохоплюючий характер.

Висновки. Використовуючи патріархальний, фреміністичний та андрогінно-аналітичний підходи до вивчення гендерних проблем у системі освітнього простору, можна сказати, що мета-антропологічна методологія є евристично плідною для розуміння феномена гендеру.

Ключові слова: освіта; соціальний простір; чоловіче і жіноче начало; гендерна рівність; стратегії освітнього простору

E. M. Gerasymova, Doctor of Philosophy, Professor

S. A. Krylova, Doctor of Philosophy, Professor

\section{SOCIAL DIMENSION OF EDUCATIONAL SPACE GENDER STRATEGIES}

Urgency of the research. For modern Ukrainian society, the issue of deep understanding of the concept of gender equality becomes especially relevant. This interest is due to the presence in the modern educational process of both men and women in the field of communication between teachers and at the level of interaction between students.

Target setting. Today we note the emergence of a new quality of relationships between men and women, which create extraordinary situations in the process of constant professional interaction and in everyday life.

Actual scientific researches and issues analysis. Consideration of theoretical and methodological principles of modern educational space, including the study of gender resource 
opportunities in the works of such Ukrainian philosophers as L. Garmash, N. Doniy, O. Zaichenko, V. Kaluga, O. Ruban, L. Tilezhenko, F. Fomin begins. etc.

Uninvestigated parts of general matters defining. Accordingly, the authors proposed to analyze the interaction and constructive possibilities of applying such gender strategies in the modern educational space as masculine-subordinate, feminine-coordinative and androgynous-holistic or humanistic. First, it is a masculine-subordinate strategy, which primarily means a clear subordination and monologue in the educational process, and its use can have both positive and negative consequences when using such an approach.

The research objective. The complexity of the task, which is related to increasing the relevance of the intellectual potential of gender strategies for the educational sphere, requires their practical adaptation to the system of strategic management of the national educational space.

The statement of basic materials. The authors of the publication believe that educational issues have always been an integral part of many philosophical systems, because education in the form of knowledge has always had the ability to penetrate into all spheres of public life and was comprehensive

Conclusions. Using patriarchal, feminist and androgynous-analytical approaches to the study of gender issues in the system of educational space, we can say that meta-anthropological methodology is heuristically fruitful for understanding the phenomenon of gender.

Keywords: education; social space; masculine and feminine origin; gender equality; strategies of educational space.

DOI: 10.25140/2412-1185-2019-2(14)-19-25

Актуальність теми дослідження. В умовах фрормування наукомісткої та високотехнологічної реальності суспільного життя кардинально змінюється значення системи освіти. Вона не тільки трансформується під впливом новітніх світових перетворень, а й стає однією з головних факторів, що прискорює глобальні цивілізаційні процеси: «Сучасний соціальний простір є доволі насиченим різними складовими системами, підсистемами. Ще однією з особливостей сучасного соціального простору $€$ кризовий стан практично усіх згаданих соціальних підсистем, надзвичайно великі соціальні ризики й біфуркаційність» [1, с. 75]. Для сучасного українського суспільства особливої гостроти набуває проблематика глибинного осмислення концепту гендерної рівності. Такий інтерес зумовлено присутністю у сучасному освітньому процесі чоловіків і жінок як у сфері спілкування викладачів, так і на рівні взаємодії студентів або учнів. 3 іншого боку, проблема рівності статей в контексті освітнього простору стає надзвичайно актуальною у зв'язку з прагненням сучасних жінок досягти рівних та вільних стосунків 3 історично сформованим панівним світом чоловіків. Крім того, відкритим залишається питання глибокої внутрішньої самотності як для соціально успішних чоловіків, так і жінок.

Освітня проблематика завжди була невід'ємною складовою багатьох філософських систем, тому що освіта у формі знання завжди володіла здатністю проникати у всі сфери суспільного життя, мала всеохоплюючий характер: «Знання існують незалежно від простору. Подібно до квантових часток, вони можуть знаходитися у деяких місцях водночас» [2, с. 389], - дане порівняння демонструє, що результати людської діяльності в сфрері освіти не мають ні просторових, ні адміністративно-правових, ні гендерних меж. Освіта стає джерелом закріплення та розвитку універсальних як пізнавальних, так і практичних можливостей людини в процесі реалізації його соціально-економічних потреб. Але сучасна модель освіти $\epsilon$ результатом складної соціальної еволюції суспільства та системних метаморфоз у порівнянні з першими античними уявленнями. Сьогодні процеси глобалізації, в першу чергу, в сфері економіки призвели до появи двох принципово нових форм дискурсивних практик - це фрілософрія освіти, яка забезпечує поступ суспільства за допомогою трансляції знань, цінностей, норм культури та досвіду від одного покоління до іншого та друга форма економіки освіти, яка на рівні теоретикоекономічного аналізу має забезпечити матеріально-ресурсною базою процес відтворення певної освітньої моделі в суспільстві.

Сьогодні ми констатуємо появу нової якості стосунків між чоловіком та жінкою, які породжують неординарні ситуації у процесі постійної як профресійної взаємодії, так і в побуті. Ми також припускаємо, що ідеї та практики гендерної рівності здатні допомогти розв'язувати 
зазначені проблеми. Однак аналіз концепту гендерної рівності має цілу низку проблемних підходів, бо прагнення до такої рівності достатньо часто породжує радикально-феміністичні настрої, які по суті $€$ банальним реваншизмом по відношенню до «сильної статі». Такий реваншизм означає інфантильну, невротичну взаємодію чоловіка та жінки, яка призводить до оновлених конфліктів і нової деструкції [3, с. 82-87]. Плідні стосунки статей - це партнерські стосунки, позбавлені будь-якого реваншистського забарвлення.

Отже, ідея рівності у стосунках між чоловіком і жінкою з необхідністю повинна бути доведена до ідеї партнерства. Тим більше, що всі плідні тенденції у сучасному світі характеризуються спрямованістю людства до комунікативної відкритості, діалогічності, толерантності як найважливіших людських цінностей, що долають відчуження та екзистенційну самотність. Таке подолання можливе лише шляхом об'єднання можливостей чоловічого та жіночого начала, адже у чоловіка і жінки є екзистенційні й психологічні особливості, які взаємодоповнюють одна одну. Об'єднуючись, ці особливості дозволяють долати, здавалося б, нерозв'язні суперечності: життєвий потенціал жінкі з необхідністю виходить за межі родини у соціальну й духовну царини, породжуючи нові ціннісні стратегії людства. Проте екзистенційний та психологічний потенціал жінки не повинен витісняти відповідний потенціал чоловічого начала. Історія на зламі тисячоліть вчить, що зазначені потенціали повинні об'єднатися, причому не просто механічним шляхом, а на засадах творчої взаємодії та самовдосконалення.

Постановка проблеми. Складність завдання, що пов'язана з підвищенням актуальності інтелектуального потенціалу гендерних стратегій для освітньої сфери діяльності, вимагає їх практичної адаптації до системи стратегічного управління національним освітнім простором, тому ефективні стратегії менеджменту освіти стають одними з головних способів вирішення загальних проблем соціально-економічного поступу України.

Аналіз останніх досліджень і публікацій. В історії фрілософрської думки є безліч різноманітних концепцій присвячених проблемам статі, але у нашому дослідженні хочеться зупинитися на найбільш оригінальних та завершених. Так, Платон вважає, що стать з'явилась у результаті трагічного розриву андрогінної цілісності. Заздрість богів призводить до руйнації такої цілісності та появи статі, тому тільки через любов між чоловіком і жінкою, на думку Платона, можна подолати відчуженість людського буття.

Видатний фундатор філософії персоналізму М. Бердяєв продовжує та розвиває міркування Платона, визначаючи ідею андрогінізму центральною у своїй фрілософії статі. Він вказує на положення про те, що «стать - це розрив. Поки залишається цей розрив - немає індивідуальності, немає цілісної людини... Чоловік тільки стать, половина, він продукт світової розірваності... I жінка - стать, половина» [4, с. 25]. Можемо стверджувати, що процес подолання статевої розірваності Бердяєв вбачає в подоланні статі завдяки ствердженню нової цілісної індивідуальності, надалі відбувається процес з'єднання з іншою цілісною індивідуальністю через любов-андрогінізм, що долає розділеність людини.

Принципово іншу позицію зустрічаємо у О. Вейнінгера, який вважає, що продуктивне з'єднання статей не є необхідним процесом. Більше того, воно й не може бути здійсненним. У роботі «Стать і характер» він приписує чоловічому все позитивне та цінне, а жіноче є лише відображенням і тінню чоловічого: «Жінка тяжіє до чоловіка так, як футляр до коштовностей. Його погляди стають її поглядами, його симпатії - її симпатіями, його антипатії - її антипатіями» [5, с. 289]. О. Вейнінгер є одним з небагатьох фрілософрів, які свідомо постулюють позицію зневаги до жіночого начала. Якщо ця зневага у більшості мислителів патріархальної доби існує на підсвідомому та контекстуальному рівні (наприклад, у 3. Фрейда та його школи), то у текстах Вейнінгера вона виривається на поверхню. Цей автор послідовно постулює те, що інші патріархальні мислителі мали на рівні передчуття про те, що жіноче є вторинним по відношенню до чоловічого начала, так як у західній культурі з моменту ствердження патріархату жіноче та чоловіче стали порівнювати як матерію та дух.

Відповіддю патріархальним поглядам на стать формуються феміністичні ідеї. У феміністичних теоріях відбувається спроба надати жінкам рівні права з чоловіком. Так, оригінальні роздуми про стать та різницю в психологічному розвитку чоловіка і жінки ми спостерігаємо у працях американського антрополога - психолога К. Гілліган. Вона переконана, що статева ідентичність у дитини формується до трьох років, коли з нею більше спілкується мати. 3 точки зору Гілліган, вже у віці трьох років у хлопця формується усвідомлення своєї 
протилежності матері, саме це зумовлює особистісний розвиток чоловіка по лінії прогресу автономії, а такий підхід вимагає особливого типу комунікативних зв'язків, який потребує моралі справедливості. У дівчат, в яких статева ідентифікація відбувається через ототожнення 3 матір'ю відповідно формується мораль любові та турботи. Тому особистісний розвиток жінки визначається усвідомленням значущості взаємодії між людьми, а тому головна проблема жінки - це збереження відносин між людьми.

Поруч із патріархальним та феміністичним підходами щодо проблеми статі сьогодні формується андрогін-аналітичний підхід, автором якого $€$ Н. Хамітов. Він пропонує послідовну та завершену концепцію статі та любові, що виходить за межі як патріархальних, так і феміністичних настанов. Сутність андрогін-аналітичного підходу полягає у визнанні не лише рівноправності чоловічого та жіночого начал, а й у постуляції необхідності їх партнерської взаємодії на психологічному, соціальному та екзистенційному рівнях. В андрогін-аналізі ключовим стає концепт екзистенційного андрогінізму, який описує динамічну цілісність людської особистості та відносин між особистостями завдяки гармонійному зростанню як чоловічого, так і жіночого начал людського буття. Методологічною основою андрогін-аналізу є метаантропологія - вчення про екзистенційно-особистісні виміри людського буття та умови плідної комунікації у цих вимірах, а також про фундаментальні тенденції розвитку людського роду і пов'язані з ними колізії. Міркуючи з метаантропологічних позицій над проблемою поза-тілесних виявів статі, Хамітов Н. вважає екзистенційним проявом чоловічого духовне начало - здатність до творчості, виходу за свої межі, самотрансцендування, а екзистенційним проявом жіночого називає душевне начало - здатність до любові та співчуття [6, с. 225 - 228], на відміну від О. Вейнінгера, який ототожнює жіноче начало з матеріальним та буденним.

Погоджуючись з позицією, що гендерна проблематика освітнього простору займає унікальне положення в системі гуманітарного знання звертається увага на такі загальнотеоретичні роботи зарубіжних і вітчизняних науковців, як М. Бубер, А. Камю, Н. Луман, Н. Маркузе, Е. Муньє, П. Рікер, 3. Фрейд, П. Тейяр де Шарден, А. Швейцер, К.-Г. Юнг Започатковується розгляд теоретико-методологічних засад сучасного освітнього простору, у тому числі дослідження гендерних ресурсних можливостей в роботах таких українських фрілософів як Л. Гармаш, Н. Доній, О. Зайченко, В. Калуга, М. Препотенська, О. Рубан, Л. Тілеженко, Т. Троїцька, Ф. Фомін тощо; розвідки ціннісно-смислового контексту освітнього простору, гуманітарні та наукові стратегії входження України у XXI століття належать відомим вітчизняним фрілософрам В. Андрущенку, В. Бобрицький, С. Кримському, В. Лук'янцю, М. Поповичу, С. Терепищему, Н. Хамітову та багатьом іншим дослідникам.

Отже, сьогодні ми спостерігаємо, як всередині вітчизняної системи освіти збільшується процес мовної, етнокультурної, соціальної та економічної розрізненості, яка з часом може привести до появи альтернативних систем духовних та виховних цінностей, що стане одним 3 внутрішніх фракторів процесу руйнування єдиного державного простору. Крім того, вітчизняна освітня криза доповнюється кризою світової системи освіти, яка не змогла мобільно адаптуватися до викликів сучасності у вигляді нової системи цінностей інформаційної цивілізації, тому дослідження гендерних аспектів зазначених процесів $є$ безперечно актуальною проблемою.

Виділення недосліджених частин загальної проблеми. Використовуючи патріархальний, феміністичний та андрогін-аналітичні підходи авторами було запропоновано проаналізувати взаємодію та конструктивні можливості застосування таких гендерних стратегій у сучасному освітньому просторі, як маскулінно-субординативна, фемінно-координативна та андрогінноцілісна або гуманістична.

Постановка завдання. Метою даної публікації є дослідження соціального виміру гендерних стратегій освітнього простору в умовах сучасного процесу глобалізації.

Виклад основного матеріалу. Проаналізувавши патріархальний, фреміністичний та андрогін-аналітичний підходи дослідження гендерної проблематики в системі освітнього простору можемо стверджувати, що метаантропологічна методологія $є$ евристично плідною для осягнення френомену статі. Головною тут стає ідея трьох екзистенційних вимірів людського буття, яка відкриває нові обрії для осягнення гармонічної взаємодії чоловічого та жіночого начала, а також осмислення деструктивних позицій в їх стосунках. Автори підтримують ідею умовного поділу буття людини на рівні буденного, граничного та метаграничного. Сенсом 
буденного буття стає такий його вимір, коли людиною керують воля до самозбереження, а також воля до продовження роду. У ситуації буденних відносин стосунки між чоловіком і жінкою формуються відповідно до таких моделей: «Я - Воно» або «Я - Об'єкт». Буденне буття породжує процес маніпуляції однієї статі іншою. Екзистенційно кожна людина відчуває в буденності свою розірваність і статеве відчуження. Такий підхід доволі часто примушує жінку відчувати те, що вона є саме жінкою, а не особистістю, а чоловік зосереджується на своїй маскулінній ролі. Актуалізуються фрізично-тілесні та соціальні якості людини, а не особистісні. Культивуються інтереси роду, а не персони. Людина спрямовує свої сили передусім на буття роду, а не на свою самоактуалізацію та самореалізацію.

У свою чергу, ситуації граничного буття людиною керують інші типи пристрастей: воля до влади, з одного боку, і воля до самотворення та культуротворення. Воля до влади зумовлює граничне посилення маніпуляції однієї статі іншою. Саме на шляху волі до влади ворожнеча між чоловіком та жінкою стає найбільш болючою, прикладом такого типу влади може бути садомазохістичний зв'язок. Воля до самотворення та культуротворення в граничному бутті спрямовує особистість до усамітнення. Причому усамітнення 3 метою саморозвитку знов відчужує чоловіка і жінку, а створені ними артефракти культури навпаки розділяють їх. Позитивним моментом у такому стані усамітненні $€$ той фракт, що відбувається становлення та актуалізація самої особистості.

В метаграничному бутті, де людиною керують такі види прагнень як воля до толерантності та воля до любові, відбувається об'єднання чоловічої та жіночої статей завдяки любові. Жінка і чоловік як біологічні статі, розвиваючи свою психологічну стать, стають цілісними особистостями і складають андрогінне ціле. Воно не стає простим симбіотичним зв'язком, а формує творче об'єднання двох автономно актуалізованих особистостей.

Отже, подолати розірваність і роздільність людини можна завдяки аналізу особливостей внутрішнього світу чоловіка і жінки, а також процесу створення внутрішньої цілісності та знаходження своєї любові.

Визначаючи найважливіші особливості чоловіка та жінки, ми звернемося до тези про те, що окрім біологічної статі, кожна людина має й соціальну стать, яка формується під впливом виховання у сім'ї та завдяки існуючому оточенню. Останнім часом, переважно у феміністичній літературі, найчастіше говориться про гендер як соціальний вимір статі, зміст його складається із соціальних стереотипів щодо ролей чоловіка або жінки. Біологічну і соціальну стать у процесі їх поєднання можемо охарактеризувати як зовнішню стать, причому вона не обирається людиною - це якби її припис. Натомість психологічний, а тим більше екзистенційний виміри статі завжди є результатом вільного вибору особистості за межами буденного буття людини. Психологічну та екзистенційну стать можна умовно назвати внутрішньою статтю або внутрішнім виміром статі. У тій мірі, в якій буття чоловіка та жінки є людським буттям, його визначає саме внутрішня стать.

Отже, можна визначити найважливіші екзистенційні та психологічні особливості чоловіка та жінки у вигляді внутрішньої чоловічності та жіночності.

Найбільш визнаними в суспільстві чоловічими рисами вважаються самостійність, вміння постояти за себе, незалежність від впливу оточення, витримка, організаторські здібності, схильність до ризику, рішучість, наполегливість, сміливість, амбітність, честолюбство, сила волі та ін. У свою чергу, жіночими рисами будуть: поступливість, чутливість до проблеми інших людей, сором'язливість, ніжність, уміння вмовити, переконати, розвинута інтуїція, жалісливість, вірність, надійність, турботливість, балакучість, сентиментальність. Різниця жіночості та чоловічості витікає хоча б з того, що потреба в самозбереженні та продовженні роду притаманна саме для жінки, вона є хранителькою вогнища; чоловік - завойовував просторів, опановувач земель, голова свого роду.

Серед багатьох рис внутрішньої жіночості та чоловічості спробуємо виокремити архетипові, які конкретизують на рівні поведінки душевність і духовність. Для внутрішньої жіночості це, передусім тактовність, гнучкість, психологічність, а для внутрішньої чоловічості - пріоритет субординації, твердість у відстоюванні своєї позиції, стратегія мислення та філософічність. Відзначаючи певні природні передумови цих ролей і їх адаптивну органічність в буденному бутті, не можна погодитись з позицією авторів, які виводять різницю чоловічої та жіночої психології й екзистенції лише з різниці анатомії та фрізіології. Осмислення вказаних вище ознак 
чоловічості та жіночості через призму метаантропології дозволяє зробити висновок, що опозиції «тактовність - стратегічність» і «психологічність - фрілософрічність» окреслюють буття чоловіка і жінки у граничному та метаграничному бутті, а такі специфічні жіночі риси як психологічність, тактовність, гнучкість, тактовність відображають той факт, що жінка як берегиня відносин має мудрість душевності - здатність до плідної комунікації, емпатії та співчуття, можливість переживати самоцінність теперішнього. Тактичність і тактовність невипадково розрізняються. Тактовність є рисою, що сприяє толерантності у спілкуванні. Тактовність можна розглядати як орієнтацію на теперішний час і прийняття значущості буттєвої ситуації «тут, тепер і зараз». Внутрішня чоловічність, яка виявляється в таких рисах як стратегічність й фрілософрічність, може бути пояснена інтенцією чоловічого начала вийти за межі буденних можливостей людського, змінитися самому та змінити світ, завоювати свободу. Всі перераховані особливості внутрішньої чоловічості та жіночності є цінними та необхідними, але вони розквітають лише доповнюючись протилежними. Тому подолати відчуженість статей можна шляхом конструктивного взаємодоповнення чоловічих та жіночих рис у духовно-душевному спілкуванні та співпраці чоловіка і жінки.

Однак, не слід забувати, що внутрішня чоловічість та жіночість є ознакою кожної особистості незалежно від біологічної статі. $€$ жіночні чоловіки - ті, що мають внутрішні риси жінки і чоловічні жінки - ті, яким властиві риси чоловіка. Внутрішня стать може гармоніювати з біологічною, а може суперечити біологічній статі, а подеколи й соціальній.

Отже, взаємодоповнення чоловічих та жіночих рис повинне відбуватися не лише у комунікації особистостей, а й у межах особистості.

У контексті сьогодення надзвичайно актуальним є звернення до гендерних стратегій освіти, які передусім реалізуються через особистість викладача. Архетиповою стала маскулінна чи патріархальна стратегія особистості викладача, який застосовує субординацію в навчальному процесі. Маскулінно-субординативна стратегія викладача має свої як позитивні, так і негативні риси. Дійсно, субординація в освіті $є$ необхідною умовою ефективного процесу навчання, але, по-перше, недостатньою, а по-друге, виходячи за певну межу, така стратегія побудови стосунків призводить до панування авторитарності та відношення до іншого як до об'єкту. 3 іншого боку, останнім часом все більше поширюється координатна освітня стратегія, яку в контексті нашого дослідження можна було б назвати фемінно-координативною. Така стратегія особистості викладача має свої позитивні риси, такі як гнучкість, терпимість, а паралельно й негативні: відсутність стратегічного підходу, системності, визначеної структурності. Виникає питання: чи $є$ можливим процес конвергенції маскулінно-субординативної та фемінно-координативної стратегій освіти, який би поєднував їх позитивні риси? У результаті таких міркувань було запропоновано андрогінну (андрогінно-цілісну) або гуманістичну стратегію. Вона передбачає вихід за межі монологічного характеру навчального процесу у площину співтворчого діалогу зі студентами, аспірантами, учнями. Проте така стратегія освіти може бути плідною та конструктивною, за умови синтезу маскулінно-субординативного і фемінно-координативного підходів, який відбувається не лише у навчальному процесі, а й у життєвому світі особистості.

Отже, можемо стверджувати, що андрогінна особистість передусім $є$ цілісною особистістю, в якій гармонійно поєднані духовне та душевне начала - глибинна чоловічість та жіночність. Цілісність андрогінної особистості зумовлює ії творчий характер. Але це особистість, яка спрямована не на будь-яку творчість, а на андрогінну творчість - творення цілісності в людському бутті як краси відносин та вчинків, творення єдності духовного та душевного начал.

Значною мірою можна стверджувати, що андрогінна особистість - це особистість, яка здатна до творення любові, що $€$ і самотворення, і творення стосунків 3 Іншим. Можна цілком погодитись з М. Бердяєвим, який, пропонуючи ідею творчого андрогінізму, вважає, що «любов акт творчій, він долає... природну необхідність. У любові стверджується особистість, єдина, неповторна» [4, с. 25]. Проте творення любові як найбільш плідних стосунків зі світом можливо лише за умови поєднання любові до Інших та любові до себе. Андрогінна особистість - це особистість, що здатна любити себе. Людину, яка рівноцінно любить і себе, і інших, Ю. Рюріков цілком справедливо називає егоальтруїстом [7, с. 120]. У цьому контексті можна пригадати вислів Мейстера Екхарта: «Якщо ти любиш себе, ти любиш усякого іншого також, як себе. Поки ти любиш іншого менше, ніж себе, тобі не вдасться любити себе як треба; але якщо ти любиш всіх однаково, і себе також, то ти любитимеш їх як єдиного, і цей єдиний є і Бог, і людина. Отже, 
великий та праведний той, хто люблячи себе, любить також й усіх інших» [8, с. 143]. Любов до себе надає можливість кожній людині зрозуміти, що окрім тілесності, вона також має духовне і душевне начала, які у поєднанні складають особистість; саме така взаємодія створює екзистенційне підґрунтя толерантного ставлення до інших особистостей. Справжня любов і повага до себе дозволяє вихователю так само ставитися і до своїх учнів, і до колег.

Висновки. Досліджуючи проблематику гендерних стратегій сучасного освітнього простору нами було запропоновано три види таких стратегій. По-перше, це маскулінно-субординативна стратегія, яка передусім означає чітку субординацію та монологічний характер освітнього процесу, причому її використання може мати як позитивний, так і негативний характер наслідків застосування такого підходу. По-друге, фемінно-координативна стратегія теж має як свої позитивні риси, наприклад, гнучкість і терпимість при освітньо-виховному процесі, так і негативні моменти: відсутність стратегічного підходу, системності, визначеної структурності. Зазначені риси також необхідні, але не $є$ достатньою умовою ефективного навчання. Третя андрогінноцілісна або гуманістична стратегія освіти трактується як процес конвергенції маскулінносубординативної та фемінно-координативної стратегій, що поєднує всі їх позитивні риси і сприяє актуалізації цілісної особистості.

\section{Література}

1. Доній, Н. Є. Освітній простір як постачальник капіталу знань для суспільства майбутнього / Н. Е. Доній // Sophia Prima: діалог вічного повернення. - 2019. - № 1. - С. $74-80$.

2. Стюарт, Т. Интеллектуальный капитал. Новый источник богатства организаций / Т. Стюарт // Новая постиндустриальная волна на Западе. Антология / под ред. В. Л. Иноземцева. - М. : Academia, 1999. - 492 с.

3. Хамітов, Н. Інфрантильність та зрілість у людському бутті / Н. Хатімов // Філососрсько-антропологічні читання'99. - К., 2000. - С. 82-87.

4. Бердяев Н. Эрос и личность. Философияя пола и любви / Н. Бердяев. - М., 1989. - 224 с.

5. Вейнингер, О. Пол и характер / О. Вейнингер. - М., 1992. - 233 с.

6. Хамітов, Н. Екзистенційний вимір статі / Н. В. Хамітов // Людина в есенційних та екзистенційних вимірах. - К., 2004. - С. 225 - 227.

7. Рюриков, Ю. Мед и яд любви / Ю. Рюриков. - М. : Мол. гвардия, 1990. - 446 с.

8. Фромм, Э. Искусство любить / Э. Фромм // Душа человека. - М. : Изд-во политической литературы, 1992. - 434 с.

\section{References}

1. Donii, N. Ye. (2019). Osvitnii prostir yak postachalnyk kapitalu znan dlia suspilstva maibutnoho [Educational space as a supplier of knowledge capital for the society of future]. Sophia Prima: dialoh vichnoho povernennia - Sophia Prima: dialogue of eternal recurrence, 1, 74-80 [in Ukrainian].

2. Stewart, T. A. (1999). Intellektualnyy kapital. Novyy istochnik bogatstva organizatsiy. Novaya postindustrialnaya volna na Zapade. Antologiya [Intellectual Capital: The New Wealth of Organizations. A new post-industrial wave in the West. Anthology]. V. L. Inozemtsev (Eds.). Moscow: Academia [in Russian].

3. Khamitov, N. (2000). InfantyInist ta zrilist u liudskomu butti [Infantilism and maturity in human existence]. Filosofsko-antropolohichni chytannia - Philosophical and Anthropological Readings, 99, 82-87 [in Ukrainian].

4. Berdyaev, N. (1989). Eros i lichnost (Filosofiya pola $i$ lyubvi) [Eros and personality (Philosophy of sex and love)]. Moscow [in Russian].

5. Veyninger, O. (1992). Pol i kharakter [Gender and character]. Moscow [in Russian].

6. Khamitov, N. (2004). Ekzystentsiinyi vymir stati [Existential dimension of gender]. Liudyna $v$ esentsiinykh ta ekzystentsiinykh vymirakh - Man in the essential and existential dimensions. (pp. 225-227). Kyiv [in Ukrainian].

7. Ryurikov, Yu. (1990). Med i yad lyubvi [Honey and the poison of love]. Moscow [in Russian].

8. Fromm, E. (1992). Iskusstvo lyubit [The art of love]. Dusha cheloveka - The human soul. (pp. 109-178). Moscow: Izd-vo politicheskoy literatury [in Russian].

Бібліографічний опис для цитування :

15.11.2019

Герасимова, Е. М. Соціальний вимір гендерних стратегій освітнього простору / Е. М. Герасимова,С. А. Крилова // Проблеми соціальної роботи: філософрія, психологія, соціологія. - 2019 - № 2 (14) - С. 19-25. 